\title{
SOLVING THE STUDENTS' PROBLEM IN WRITING DESCRIPTIVE TEXT THROUGH ATTRIBUTE CHARTS STRATEGY
}

\author{
M. Fadhly Farhy Abbas \& Shelvira Elsa Dwita \\ Universitas Lancang Kuning \\ E-mail: fadhly@unilak.ac.id \\ shelvira.elsa1306@gmail.com
}

\begin{abstract}
This research was based on the students' problems in writing descriptive text, especially in terms of organizing the generic structure, determining adjective to describe people or things, and mastering vocabulary. The purposes of this research were to improve the students' writing skill in descriptive text and to find out the factors influencing the students' improvement through Attribute Chart strategy at grade 7.2 of SMPIT Al Birru Pekanbaru. The design of this research was Classroom Action Research. The instruments used were the writing test, observation checklist, field note, and interview. The participants involved in this research were the students at grade 7.2 which was consisted of 16 students. The result showed that the students base score was 51.8, and the score in cycle 1 was 70.4. It means the students' score was improved in cycle 1. Furthermore this improvement was influenced by 4 factors. These factors were obtained based on the result of field note. Moreover, the results of field note were: students' motivation, students' interest, students' exciting with the new topic, and the students' activeness in the learning process. In conclusion, the use of Attribute Chart strategy in writing descriptive text can improve students' writing skill at 7.2 grade of SMPIT Al Birru Pekanbaru.
\end{abstract}

Keywords: Attribute chart strategy, writing skill, descriptive text

\section{MEMECAHKAN MASALAH MAHASISWA DALAM MENULIS TEKS DESKRIPTIF MELALUI STRATEGI BAGAN ATTRIBUT}

\begin{abstract}
Abstrak
Penelitian ini didasari oleh adanya masalah siswa dalam menulis teks deskriptif, terutama dalam hal mengatur struktur generik, menentukan kata sifat untuk menggambarkan orang atau hal-hal, dan menguasai kosa kata. Tujuan penelitian ini adalah untuk meningkatkan keterampilan menulis siswa dalam teks deskriptif dan untuk mengetahui faktor-faktor yang mempengaruhi peningkatan siswa melalui strategi Bagan Atribut di kelas 7.2 SMPIT Al Birru Pekanbaru. Desain penelitian ini adalah Penelitian Tindakan Kelas. Instrumen yang digunakan adalah tes, daftar observasi, catatan lapangan, dan wawancara. Peserta yang terlibat dalam penelitian ini adalah siswa kelas 7.2 yang terdiri dari 16 siswa. Hasil penelitian menunjukkan bahwa skor dasar siswa adalah 51,8, dan skor pada siklus 1 adalah 70,4. Ini berarti skor siswa meningkat dalam siklus 1. Selanjutnya peningkatan ini dipengaruhi oleh 4 faktor berdasarkan catatan lapangan, yaitu: motivasi siswa, minat siswa, minat siswa dengan
\end{abstract}


topik baru, dan keaktifan siswa. dalam proses pembelajaran. Kesimpulannya, penggunaan strategi Bagan Atribut dalam menulis teks deskriptif dapat meningkatkan keterampilan menulis siswa di kelas 7.2 SMPIT Al Birru Pekanbaru.

Kata kunci: Strategi bagan atribut, keterampilan menulis, teks deskriptif

\section{INTRODUCTION}

Studying English includes the mastery of four language skills; they are listening, speaking, reading and writing. Speaking and writing are productive skills to produce language, listening and reading are receptive skill or ability to comprehend information. The fourth basic skills are qualified in a assimilate way. Writing is a process to produce language. We can take additional time to reflect and select arguments in instruction to fast our ideas supposed and feeling, then we brand a modification uncertainty it is not perfect to definite whatever we propose to write. It is also needs attention because it needs its own principles and method it needful mastery not one of structural a verbal strategies but also of the theoretical and judgment. For that reason, it needs practice to improve that skill. In advance, it is a physiological action of the verbal user to set data in the written text. Writing is an action to make a records or data on middle by means of a script. Writing is usually done on paper by using utensils such as a pen or pencil, especially writing descriptive text. Descriptive is type of text which offerings data about something specifically. The determination of descriptive text is to term a specific person, place, and thing. The text is only show fact because descriptive show the attribute of the thing, most clauses is adjective. Descriptive text also shows part whole relationship.

Descriptive text has two components, such as identification and description. The component of a text is termed the generic structure. The first is
Identification which covers the identification of relations or introductory or the overall term of somebody or things of the topic. And second is description which covers of the explained, call of effects and someone that more part from the identification that has common describe. To create descriptive text, we have to determine the theme descriptive text then you create common term of descriptive text. The common describe that determination be make detail description. Widodo (2011) states descriptive or description describes a particular person, place or thing its purpose it to tell about the subject by describing its feature without including personal opinions. Thus, the description essay is the one describes a person, place and object. In addition, Widodo (2011) states that writing descriptive text is one of the genres in in writing texts; it is taught by teacher in order to make students know how to describe themselves and their surrounding although it is still in simple way.

From the previous studies were about writing descriptive text. From the explanation above the expert take similar ideas or similar impression about descriptive. They supposed that a descriptive is to define rather similar a person, habitation and object. Based on the school based curriculum 2006 for seven grades the education knowledge of English has the determination to progress four language skills; listening, speaking, reading and writing. The additional English language components; vocabulary, structure and pronunciation (in speech) or suggesting (in writing) are significant to be qualified to provision 
the expansion of four language skills. In short, English teachers must explain the four aspects. It is not only reading or speaking but also listening and writing so the students can main all of these skills. Students learn about writing descriptive text. Descriptive text is a text that defines a specific person, stuffs and object in detail. It is known that descriptive text uses simple present tense as the language feature and have generic structure such as, Identification and Description.

In relation to the previous explanation, it needs an answer to resolve the students complications in writing. The solution is by using Attribute Charts strategy. By using Attribute Charts the students treat themselves to accustom with the habit of writing. Attribute Charts is a way to find an current strategy to support the students in determining the appropriate adjective and furthermore to help the students writing the descriptive text in good ordering of sentences.

\section{a. Writing}

Writing is ability in knowledge language that essential be mastered by everybody particularly for students. Because writing is final project after the students learn about Listening and Reading. In addition, Abbas (2017) states that one of the writing skills that should be mastered by the students is writing an essay, the better ability the students have in writing an essay, the better ability they have in writing another form of writing such as scientific writing, argumentative essay, or various English text types. Writing is a measure of the language ability besides listening, speaking, and reading that need be educated greatly through the teacher for students. Writing is the one of skills used to deliver ideas. In learning process, writing is organized well that gives the good result for students. To do so, they need adequate knowledge of grammar, vocabulary, writing organization and background knowledge. It is therefore reading provides such kind of knowledge to stimulate ideas in writing. Writing is a technique to definite the impression or opinion through simple sentences. They develop their simple sentences in compound, complex, and complex compound sentences using subordinate conjunction. Those are to support the idea. From those, the writers produce their own language through vocabulary that they had. Referring to the statement above, Taylor (2009:2) He states that if a student is willing to be able to express his/her ideas in the written form, he/she needs someone else to guide and teaches $\mathrm{him} / \mathrm{her}$ how to do so well and appropriately.

According to Brummer and Clark in Meiliana (2010) stated that writing is a tool that allowed students to translate complex ideas into words andthe use of written language as a medium. Moreover, Suparno (2008) states that writing services is the skill to pour thoughts addicted to the verbal write complete sentences that are arranged as a whole, complete, and clear so that the ideas can be communicated to the reader to succeed.

\section{b. Teaching Writing}

There are four details for instruction writing to pupils of English as foreign language. They are reinforcement, language development, knowledge style, and writing as a skill. First is reinforcement. Particular pupils obtain language in a chastely spoken or auditory way, but greatest of students ${ }^{\text {ee }}$ advantage importantly from sighted the language written down. The graphical demonstration of language construction remains precious for our sympathetic of in what way it all hysterics composed and as an assistance to obligating the new language to memory. Students frequently 
discovery it valuable to inscribe sentences by new verbal presently afterward they take studied. Additional is language development. Students' progress their writing mostly finished writing itself. When they are writing, they make correct inscribed text towards be exploratory with the language. Third is knowledge style. Certain pupils are capable to discovery informal to choice up language fair by observing and listening. Through writing, they take considerable while to reason effects and to products language in relaxed way. Writing is suitable for learners. It be able to too be a soundless thoughtful action in its place of the haste and problem of relational head-on communication.

Fourth is writing by way of a skill. Writing is as significant by means of speaking, listening, and reading. Students essential to tell in what way transcribe letters, by what means to position written explosion is together, in what way to repetition to statements and increasingly, in what way to compose by automatic media. They are essential to tell particular of writing singular agreement (punctuation, section construction, and others.) Writing is an essential ability in students` everyday survives and that types it is actually significant feature of their teaching. Students necessity to tell in what way to income follow-ups as well as in what way to write papers and letters, which types this simple ability as significant as speaking or listening. Writing abilities are significant since they are a respectable method to strengthen what a pupil consumes educated by way of the determination advantage after sighted original words or arguments container be a paragraph. Teacher, in that circumstance wants to remain receptive to the classroom condition in instruction to income a correct measure. When serving students to develop improved writers, teachers have a number of essential errands to perform. There are quantities of critical responsibilities to perform, First is demonstrating, teachers essential to be capable to attraction about writing agreement and type restraints in detailed kinds of writing to their attention. In at all method pupils are made conscious of plan subjects or the language used to achieve positive printed functions.

The second is inspiring and provoking, students frequently discovery themselves misplaced for words, particularly in original script task. This is where the teacher container assistance irritating the students hooked on consuming ideas, stimulating pupils with the worth of the task, and persuasion them what enjoyable it canister be. The teacher enthusiasms into class with fix suggestions, so the students are able to directly get assistance rather than the reason concepts through themselves.

Third is supporting, students essential to a lot of assistance and encouragement when they become successful in cooperation by thoughts and through the resources to convey them out. Teachers' essential to be really helpful once students are writing in the class, continuously obtainable and able to assistance them overwhelmed difficulties.

The fourth is responding, when responding, teachers respond to the satisfied and creation of a part understandingly and frequently type idea intended for its improvement. When teacher reacts to students ${ }^{\text {ee }}$ workings at several current stages, he/she expresses the students how well it is successful so far.

The last is evaluating, there are several occasion, however, when the teachers do to assess students` work, effective both them and us how well they have done. All of teachers need to know the students achievement. When the 
teacher assesses students writing for examination purposes, he/she can designate where they inscribed well and where they brand mistakes.

As Sorenson (2010:3) states that good writing starts with process. According to him, there are four basic steps in writing anything: prewriting, writing, revising, and proofreading. The first is prewriting, the activities of prewriting usually help students to find a good topic, narrow topics that are too broad, and look at purpose. This is a warm-up activity in writing. The second is writing, in writing they should feel free to express their ideas without worrying about mechanical details, sentence structure and other formal writing techniques because they want to express their ideas smoothly. The third is revising; revising is an activity which needs a hard work to polish the writing. It is such as improving the content and structure. And the last proofreading, after revising, students should do proofreading. Proofreading is an Activity which focuses on getting rid of the mechanical errors, like spelling, grammar, and punctuation. Students need to read their writing several times and pay attention on each sentence. Students may ask someone else to proofread. The researcher concludes teaching writing is not easy. The teacher should give more attention about students who want to write a simple sentence or text, and also stimulated all students to be good writer.

\section{c. Descriptive Text}

Descriptive is one of the genres which must be well-read by students of junior high school. Descriptive text is a kind of the text which is used to define a specific person, place, activity, idea or thing that is drawn in words. George and Julia in Fauzi (2014) state that emotion may be described too in descriptive writing, feelings such as happiness, fear, loneliness, gloom, and joy. Description helps the readers, through their imagination, to visualize a scene or a person, or to understand a sensation or an emotion.

According to Wardiman, Jahur, Sukiman (2008) Descriptive text is a part of factual genres. It has social function which is to describe a particular person, place, or thing. The point is that descriptive provides an explanation of rather in specific in instruction to support the persons observe it finished words. From the clarification above, the researcher settle that descriptive text simply defines about person, place or thing. And the point is description created on the generic structure of descriptive text such as Identification and Description. According to Friedman (2010), descriptive details mean to grab the reader's attention. A descriptive text is considered as the simplest and easiest writing form compared to narrative, recount, or procedure, particularly for the beginning writers. Based on description descriptive text from expert above, I can conclude that descriptive text is a text which states what a person or a thing is like. The resolution of descriptive text is to describe a particular person, place, or thing.

Nadia in Purna (2013) stated that the features of a factual description have regarded as following generic structure of descriptive text. Identification (introduction) is a general opening statement in the first paragraph or the first sentence that introduces the subject of the description to the audience. Besides, it be able to provide the listeners transitory specifics about the when, where, who, or what of the subject described. Description is a sequence of sections about the topic where both paragraph typically instigates with a topic sentence. The topic sentence showed the particulars that will be 
limited in the balance of the paragraph. Moreover, each paragraph must define one piece of the topic and all paragraphs shape the explanation of the subject. The explanation can be bodily look of the subject, the makings of the topic like grade of beauty, quality or value. Besides generic structure, Descriptive text also have characteristics such as: Focus on descriptive text such as the describe someone, things, animal, and plant, using simple present tense, have an adjective as a noun explanations, and write explanation from general to specific.

\section{d. Attribute Charts Strategy}

Attribute Charts are kind of Mind Mapping, inventor of mind mapping is Buzan (1942). The researcher gives the treatment using this strategy, so whole stages of the writing Process will always be featured with the data in the Attribute Charts. The use of Attribute Charts includes the first, teacher divides students in 4 groups, the second, teacher give Instruction to imagine something such as place, animal in 5 minutes for example group 1 about animal the name of animal is tiger. The third, after the students choose an information about tiger in details, students make an attribute chart to establish the ideas, the Fifth, give instruction to students to appeal a net to support them establish details about tiger in English language, deliver informational editions to accumulate details that label bodily physical appearance that assistance animal live and thrive. The Sixth, write the numerous figure part in the highest straight section of the grid. The Seventh, write the terms of several animal type depressed the port pointer units of the grid, and the last have students seal in the net seats by evidences as of their research. According to Hall and Beggs in Sumardi (2014) content is that the key impartial of education is to simplify students' suitable valid creators of language inside common collections equally inside and outside the classroom. There are so many benefits if a teacher teaches their students using Attribute Charts strategy in teaching learning activities.

\section{METHOD}

The design of this study was a classroom action research. The researcher conducted the study collaboratively with the English teacher to solve the problem of the students' writing Descriptive by using Attribute Charts at the VII 2 Grade of SMPIT AL Birru Pekanbaru. According to Hopkins (2014) and Kemmis and McTaggart (2014) action research is about the systematic study of attempts to improve educational practice by groups of participants by means of their own practical actions and by means of their own reflection upon the effects of that action.

Action research was any sort of methodical review conduct through persons with a direct, conferred concern in the education and teaching procedure popular a specific location it is truthfully methodical review addicted to one's personal practice. Mertler (2012) states that classroom action research as a process that allows teachers to study their own classroom in order to better understand them and to be able to improve their quality or effectiveness.

Based on the explanation above, classroom action research is the way to apply theories or method in the social real or teaching process. The aim of this research is to improve the condition of teaching and learning process by using appropriate strategy or media such as attribute chart strategy in the teaching of writing descriptive text. 


\section{FINDINGS AND DISCUSSION}

This chapter shows the description of data analysis. There were two research questions that would be answered in this chapter. Firstly "To what extent can attribute chart strategy improve students' ability in writing descriptive text at the seventh grade students of SMPIT Al Birru Pekanbaru?" and secondly "What factors influence the changing of students' skill in inscription descriptive text by using quality chart strategy at the seventh grade students of SMPIT Al Birru create chart strategy on the data got from the test, observation checklist, field note, and interview.

Table 1.1 The result of students writing test from the based score to cycle 1

\begin{tabular}{lll}
\hline $\begin{array}{l}\text { Name } \\
\text { Score }\end{array}$ & Average & Categories \\
\hline Base & 51,8 & Fail \\
Score & & \\
Cycle I & 70,4 & Pass \\
\hline
\end{tabular}

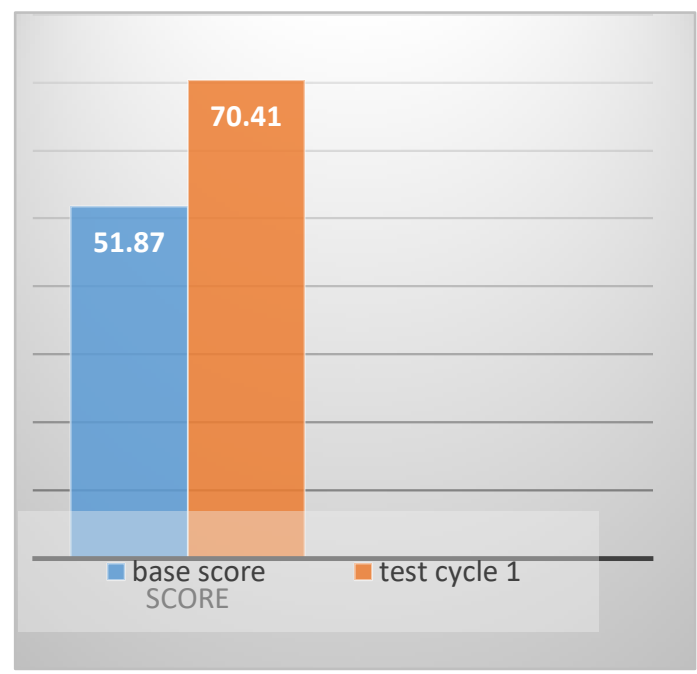

Diagram 2.1 Result of students' writing test from the based score to cycle 1
Referring to Table 1.1 and Diagram 2.1 above, it can be identified that the students' base score was very low. The average score was 51.8. However, the students' cycle 1 test was good, 70.4. There were 16 students failed. It could be identified the students had difficulties in writing descriptive text. As the English teacher said before, the students were difficult to organize the writing generic structure of Descriptive text, difficult in ordering sentences.

Table 1.2 The comparison of the students writing skill in descriptive text from based score to cycle I

\begin{tabular}{lll}
\hline Indicators & $\begin{array}{l}\text { Based } \\
\text { Score }\end{array}$ & Cycle I \\
\hline Organization & 5.12 & 7.26 \\
Grammar & 5.12 & 6.80 \\
Vocab & 5.75 & 7.49 \\
Mechanics & 4.75 & 6.58 \\
\hline
\end{tabular}

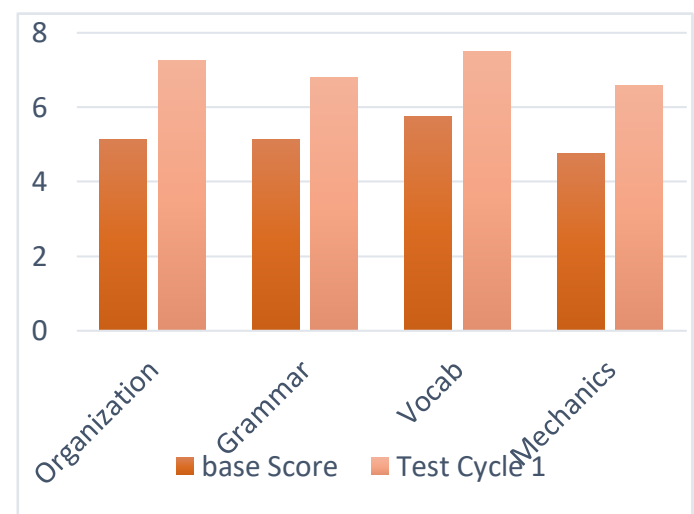

Diagram 2.2 The comparison of the students writing skill in descriptive text from based score to cycle I

Based on the table and diagram above, in organizing ideas, students got difficulties to determine adjective to describe people, or things. And the last is lack of vocabulary. For those reason the researcher has concluded that the 
students' writing descriptive text were low. The researcher had conducted teaching descriptive text based on the procedure of attribute chart strategy, and there were some observations that were done by the collaborator and the researcher. Previously, it was observed by collaborator while having teaching process by using attributes chart strategy, and also the text. This was conducted in every meeting. The collaborator also wrote notes about the class activity namely the teacher's and the students' activities in every meeting.

Furthermore, the researcher gave the writing test for the students. The aim was to know the students' ability in writing descriptive text. In this test, the researcher gave test text about "descriptive text". The average score of the first cycle test was presented below:

Table 1.3 The students score in cycle 1

\begin{tabular}{ccc}
\hline Category & $\begin{array}{c}\text { Number of } \\
\text { Students }\end{array}$ & Percentage \\
\hline Very good & - & - \\
Good & 10 & $62.5 \%$ \\
Fair & 2 & $12.5 \%$ \\
Poor & 4 & $25 \%$ \\
\hline
\end{tabular}

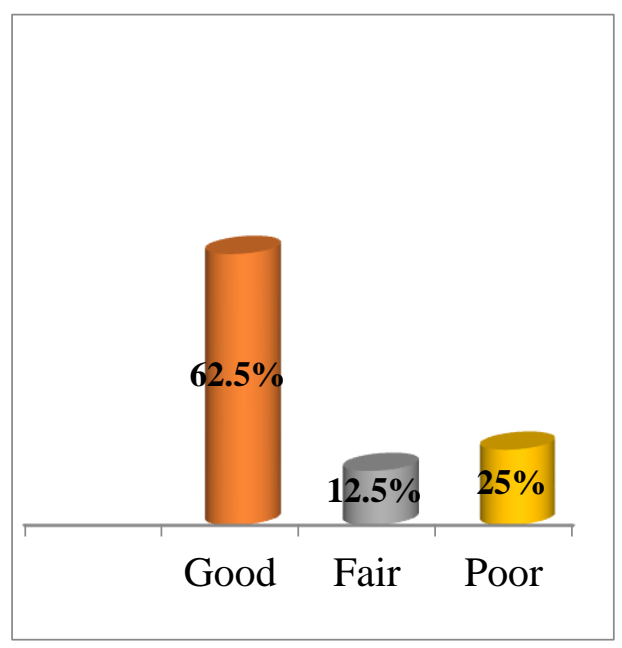

Diagram 2.3 The students score in cycle 1
Based on the Table 1.3 and Diagram 2.3, the researcher found the clear different of the students' based until cycle I score. Furthermore, the researcher and collaborator also found the factors of changing score process that will be discuss on the following discussion. The students' improving was also found in their writing descriptive text mean score of based score. The average of students' writing score in based score was 51.8 and cycle I was 70.4 with increasing point 18.5. However, there was something ran well according to interview; the students were adapted well with this new strategy, better class management by teacher and also there were created a comfort situation while learning process in the class. The last, according to data above, the teacher and collaborator decided to finish the research at this cycle because the aim had reached; students' score had improved and passed the passing grade

According to the data above, the collaborator and the researcher stated that writing descriptive text from the based score to the test cycle 1 had an improvement. The use of Attribute Chart has been made the students' result better than before. All of the students have followed the teaching and learning process. In applying Attribute Chart the researcher has found that the students' interest although the students have made the class noisy, they were active to study in the class and applied Attribute Chart well. It has been proved from the students' based score was 51,8 to cycle 1 was 70,4 with the increasing point was 18.5 Therefore, the researcher and collaborator have decided to stop the classroom action research because based on the result of cycle 1 , it was already a success based on the field note.

Based on the findings of this study, the students' writing ability was significantly improved. This is in line with the findings of previous studies 
(Sumardi, 2014) the result of this study is studentse progress during the teaching descriptive text is improved. It is supported by the average of the students ${ }^{e}$ result of the pretest (48.8) and that of the post-test (77.1). The main factor affected this success is the use of attribute chart strategy and the given material. The result of study showed that results specified a collective in the number of reply parts on paper and improved constancy in the number of arguments written. The participants who seemed the intervention as positive provided social validity.

The second Nafi'ah (2009), "The Use of Mind Mapping Technique to Improve students' Comprehension on Narrative Text" (A classroom action research at eight grade students of MTs I'anatut Thalibin Pati in The Academic Year of 2008/2009).' She identifies the occurrences that students discovery certain problems in comprehending reading English text, particularly once they find a lot of unfamiliar words which they cannot comprehend and use correctly. In her study she uses mind mapping technique in teaching reading comprehension to improve students' comprehension on narrative text. This research was conducted in three cycles and was done in five activities including the pre cycle and the post cycle. The result of study shows that using mind mapping technique is effective and can improve students' achievement in reading comprehension. This is proved by students' comprehension test that improved in every cycle.

The third, the thesis entitled "Improving Students Ability in Writing Descriptive Text through Wholesome Scattering Game (An action research at the VIII grade of MTs Sunan Ampel Patean Kendal in the academic year of 2010/2011 written by Widodo. The researcher shows that the ability in writing is improved after being taught by using wholesome scattering game. They could write easily without consuming more time because they are arranging and writing Descriptive text based on key words. This is in line with attribute chart strategy in terms of key words. They are clever to define entire of parts, qualities, and features of object. It presented by the total of pretest and every cycle. In the pretest found the total score of students writing result was 982 it means was 31,7. It means that the worth of students writing was average, but built on values assessment students are still fair. In the second cycle originate the total score of students writing results was 2095, it means was 67,6 . It was concluded that the value of students of writing result was good.

The fourth, a thesis written by Mawaddah (2009) entitled The Effectiveness of Using Mind Mapping to Improve Students Writing Skills. That strategy help the students improve their skill in writing. The researcher found that teaching descriptive text by using a mind mapping strategy is very useful both for the teacher and the students. Aimed at the teacher, he/she container clarify the physical in detail. For the students, they are additional interested since they discovery out a new object through the knowledge activity.

The fifth, a thesis written by Kholifah (2009) entitled "The Effectiveness of Strip Stories to Help Students' Sequence Events in Recount Writing" (An experimental Study at MTsN Margoyoso Pati grade VIII in the academic year of 2008/2009). In this study, she uses strip stories to teach writing recount text in the form of strip of pictures completed with key words under each strip as guide.

Established on the previous research, The researcher assumes that the custom of Attribute Chart similar to the 
previous research in terms of key words, that's why the researcher highlight the research in this chapter. And the different Attribute Chart with the previous research is in Attribute Chart there is a grid and students fill the grid with some adjective words based on object.

The factors that influenced students' Writing Skill by Using Attribute Chart Strategy can be seen from the instruments such as observations, field notes, and interview results. All of the factors were as follows: Teacher always gives motivation to students before start the learning process and warming up. Motivation has massive impact for students while doing their activity or task. By giving motivation to students, teacher hope that students can do their job excellently and having an improvement according to test, observation checklist, field note and interview. This Strategy could make students' active, according to the rules of the strategy students could make an activity more than their latest knowledge procedure then the students could consume massive discussion in the class with their group members. This strategy needs group to run according to the rules, so students divided into some groups and every group has members. So they can make a discussion with their friends to decide what idea would be pour or write based on the attribute chart they had arranged.

From based score, the students' mean score was 51.8, and it was increased in cycle 1, the mean score was 70.4. It means that attribute chart strategy could better improve the students' ability in writing descriptive text. The increased point from based score to cycle 1 was significant, moreover the improvement could be seen in the number of students who can reach the transitory score criteria in which in cycle 1 , there were ten students passed, otherwise in based- score there is no students who could pass the passing grade criteria.

The strengths of Attribute Chart strategy in teaching writing Descriptive text such as most of students' were interested in learning writing skill. This strategy was new for the students'. They have known because their latest learning process. And then, most of students' were active and excited in learning process. Rules of the strategy applied were conducted in group form members while learning process.

Furthermore, the weaknesses of Attribute Chart strategy in education text Descriptive text are: some of students were confused in finding information into the text, because not everybody have background knowledge about the topic given and not everybody can work well in a group. So, the students' should solve the problems by reading a lot of text and make a small group for training their ability in working in a group. And the last some of students were disturbed their friends when writing descriptive text based on text given. So the teacher should know how to handle the class to create comfort situation.

Finally, the researcher concluded it is true that using Attribute Chart was able to give significant improvement to students' writing skill in descriptive text at the seven grade of SMPIT Al Birru Pekanbaru. According to students' achievements in the test, it was shown significant improvements at the end of cycle I. But, it cannot be denied or covered especially in form of improving students' grammar and mechanics in writing descriptive text, it showed from students' score for each indicator. They were good in generating idea such as organization and vocabulary; but they were low in grammar and mechanics. It showed that they had low score at the end of cycle I. The data of this research will be discussed happening instruction to 
response the study questions; to what extent Attribute Chart could develop the students' writing ability in descriptive text at the Grade VII 2 of SMPIT Al Birru Pekanbaru and what factors influenced the improving students' writing skill in descriptive text at the Grade VII 2 of SMPIT Al Birru Pekanbaru.

\section{CONCLUSION}

After conducting this classroom action research in writing Descriptive text through Attribute Chart strategy, the researcher concludes this research into some conclusions as follows :

1. Teaching writing in Descriptive text through Attribute Chart strategy is able to improve the students writing skill. It is supported by the improvement of the students score from 51.8 to 70.4 .

2. The students' improvement is influenced by 4 factors they are motivation, interest, excited, and active. The conclusions above are taken from the instruments used in this research; such as tests, observation checklists, field notes, and interviews. According to datas in cycle I, the researcher find there was significant improvement by students according to the intruments. Based on the test, the average score in base score is 51.8 and cycle $\mathrm{I}$ is 70.4 with increasing point 18.5 .

\section{BIBLIOGRAPHY}

Abbas, M. (2017). Fadhly Farhy. 2017. Assessing and Evaluating EFL Learners' ability in Writing Academic Essay. Proceedings of ISELT FBS Universitas Negeri Padang, 5, 257-261.
Fauzi (2014). Improving Descriptive Text Writing Ability of The Eight Grade Students of SMPN 3 Gianyar in Academic Year 2013/2014, English Education Study Program Faculty of Teacher Training and Education Maharaswati University Denpasar, unpublished thesis.

Friedman, L.S. (2010). Writing the Critical Essay: Euthanasia.

Hopkins, (2014). A Teacher Guide to Classroom Research: Open University Press.

Kemmis, S. and McTaggart R. (2014). Participatory Action Research. California: Sage.

Kholifah. (2009). The Effectiveness Of Strip Stories To Help Students' Sequence Events In Recount Writing (An Experimental Study at MTs $N$ Margoyoso Pati Grade VIII in The Academic Year of 2008/2009). Semarang: State Institute For Islamic Studies), unpublished thesis.

Mawaddah, L. (2009). The Effectiveness of Mind Mapping Strategy in Teaching the Students to Write Descriptive text (An Experiment of the Eight Grade Students of SMPN 1 Pegandon Kendal in the Academic Year of 2008/2009. English Department Faculty of Language and Arts, Semarang State University), Unpublished thesis.

Meiliana, F. (2010). Teaching Writing by Combaining Frayer Model and Quick Write Strategies at Senior High School. STKIP PGRI Sumatra Barat. 
Mertler, (2012). Classroom Based Action Research. Florida: Centre for Learning Excellent.

Nafi'ah. (2009). The Use of Mind Mapping Technique to Improve students' Comprehension on Narrative Text" (A Classroom Action Research at Eight Grade Students of MTsI'anatut Thalibin Pati in The Academic Year of 2008/2009). Semarang:State Institute For Islamic Studies), unpublished thesis.

Purna, Ni Ketut Anna. (2013). Improving Descriptive Text Writing Ability of The Eight Grade Students of SMPN 3 Gianyar in Academic Year 2013/2014 by Using Short Video Clip. Denpasar: Maharaswati University Denpasar), unpublished thesis.

Sorenson, Sharon. (2010). Students Writing Handbook (fifth Edition. Canada: Willey Publishing Inc.

Sumardi. (2014). The Use of Attribute Charts Strategy to Improve Students Ability in Writing Descriptive text ( A Classroom Action Research to the Seven Grade Students of SMPN 18 Semarang in Academic Year 2013/2014. English Department Faculty of Language and Arts Semarang State University), unpublished thesis.

Suparno (2008). Keterampilan Dasar Menulis. Jakarta: Universitas Terbuka.
Taylor, G. (2009). A Student's Writing Guide. How to Plan and Write Successfully Essay. Cambridge University Press.

Wardiman, Artono., Jahur, Masduki B, Sukiman, M. (2008). English in Focus: For Grade Seven Junior High School SMP/Mts. Jakarta: Depdiknas.

Widodo. (2011). Improving Students Ability in Writing Descriptive text Through Wholesome Scattering Game (An Action Research at the VIII grade of Mts Sunan Ampel Patean Kendal in the academic year of 2010/2011. Semarang: State Institute for Islamic Studies), unpublished thesis. 